\title{
The importance of ants and high-shade management to coffee pollination and fruit weight in Chiapas, Mexico
}

\author{
STACY M. PHILPOTT ${ }^{1,4, *}$, SHINSUKE UNO $^{2}$ and \\ JORGE MALDONADO ${ }^{3}$ \\ ${ }^{1}$ Department of Ecology and Evolutionary Biology, University of Michigan, 830 N. University Ave., \\ Ann Arbor, MI 48109-1048, USA; ${ }^{2}$ School of Natural Resources and the Environment, University of \\ Michigan, 430 E. University Ave., Ann Arbor, MI 48109-1115, USA; ${ }^{3}$ c/o El Colegio de la Frontera \\ Sur (ECOSUR), Carretera Antiguo Aeropuerto, Km 2.5, Tapachula, Chiapas 30700, Mexico; \\ ${ }^{4}$ Present address: Smithsonian Migratory Bird Center, National Zoological Park, 3001 Connecticut \\ Ave NW, Washington DC 20008, USA; *Author for correspondence (e-mail: philpotts@si.edu; \\ phone: +202-633-4206, fax: + 202-673-4916)
}

Received 12 August 2004; accepted in revised form 24 June 2005

Key words: Coffea arabica, Ecosystem services, Pollinator and ant diversity, Shade management system

\begin{abstract}
Recent reports show importance of pollinators to coffee and importance of ants as pollinators or floral protectors in many systems. Arthropod and pollinator diversity, however, declines with management intensification of coffee (Coffea arabica) agroecosystems. We investigated influences of both flying pollinators and ants on coffee fruit set and fruit weight in one highshade (high-biodiversity) and one low-shade (low-biodiversity) coffee farm in Chiapas, Mexico through exclusion experiments. Contradictory to previous reports, flying pollinators alone did not affect coffee fruit set or fruit weight. Individual fruit weights, however, were higher on branches with both ants and flying pollinators (1.78 $\mathrm{g} \pm 0.312$ (SE)) compared to branches without ants $(1.03 \pm 0.029)$ or branches without ants or flying pollinators $(1.05 \pm 0.049)$, but only in the highshade site. Although the mechanisms producing higher fruit weights are unknown, we discuss how ants or ant-flying pollinator interactions under high-shade coffee management may contribute to increased fruit weight and the implications of high-shade management for both sustainable coffee production and biodiversity conservation.
\end{abstract}

\section{Introduction}

Pollinators provide ecosystem services (benefits to humans resulting from ecological functions) in agricultural and natural ecosystems especially where pollinator diversity or abundance is high. Studies highlight necessary or positive influences of particular pollinators (Pimentel et al. 1997; Allen-Wardell et al. 1998; Kearns et al. 1998; Norberg 1999; Cunningham et al. 2002; Kremen et al. 2002). Additionally, pollinator (specifically bee) diversity and abundance can increase pollination rates and fruit or seed set (Rathcke and Jules 1993; Aizen and Feinsinger 1994; Steffan-Dewenter and Tscharntke 1999; Kremen et al. 2002; Klein et al. 2003b; Ricketts et al. 2004). Although some 
argue that pollinator biomass is alone sufficient to maintain pollination services (Myers 1996), there is still much debate regarding the importance of pollinator diversity (Balvanera et al. 2001).

Although ants are not often considered pollinators, and in fact sometimes negatively affect plant reproduction, ants may enhance pollination in some cases. Ants are nectar thieves (Galen 1999; Ghazoul 2001), flower predators (Galen and Cuba 2001), and may reduce pollen viability via antibiotic secretions (Beattie et al. 1984; Ramsey 1995; Wagner 2000). Some plants even have chemical (Willmer and Stone 1997; Wagner and Kay 2002) or mechanical defenses (Guerrant and Fiedler 1981) to deter ants. Many studies, however, show either direct or indirect benefits to plants via their interactions with ants. Ants do visit flowers and act as pollinators (Gomez and Zamora 1992; Garcia et al. 1995; Gomez et al. 1996). Despite that ants are considered less efficient pollinators, ants may pollinate plants as effectively as winged insects especially when considering germination, seedling survival, and growth to reproductive maturity in addition to seed set (Gomez 2000). Ants benefit plant reproduction indirectly by limiting floral predators (Yano 1994; Oliveira 1997; Sporleder and Rapp 1998; Oliveira et al. 1999). Ants also may augment pollination success by attacking pollinators subsequently increasing their movement and thus pollen transfer between flowers (Altshuler 1999).

Arthropod (including ant and flying pollinator) diversity generally declines with increasing management intensification in coffee (Coffea arabica) agroecosystems (Perfecto and Snelling 1995; Perfecto and Vandermeer 1996; Klein et al. 2002). Intensified coffee systems are generally characterized by high use of agrochemicals and fertilizers and a reduction or total elimination of shade trees (Moguel and Toledo 1999) and shade composition or cover may affect species richness (e.g. Perfecto and Vandermeer 1996; Calvo and Blake 1998). It is not clear, however, what this decline in richness may mean for coffee pollination.

Arabica coffee is a self-compatible species that may or may not benefit from pollinators. High numbers of visits of one species of pollinator (Apis mellifera) correlate to increased coffee fruit set and fruit weight (Raw and Free 1977; Manrique and Thimann 2002; Roubik 2002). Furthermore, some studies have shown the importance of a diverse suite of pollinators (including both social and solitary bees) to coffee pollination (Klein et al. 2003a, b) and pollen deposition (Ricketts 2004). Some researchers, in contrast, have found that coffee does not significantly benefit from insect pollinators (Nogueira-Neto et al. 1959; Sein 1959). No studies, however, specifically separate the effects of bees from other pollinators, possibly including ants, which also visit coffee flowers (Free 1993) and may be coffee pollinators (Klein et al. 2003b).

In order to study the importance of pollinators under two coffee management systems, and the possible importance of ant as pollinators, we set up pollinator exclusion experiments to test the following hypotheses: (1) If flying insects pollinate coffee, and if coffee responds to these visits, fruit set or fruit weight will increase on plants with flying pollinators compared with pollinator 
exclosures, (2) If ants directly or indirectly beneficially influence coffee pollination, fruit set or fruit weight will be higher on plants with ants than on ant exclosure plants, (3) If a diverse pollinator array benefits coffee, fruit set or fruit weight will be higher where pollinator diversity is also higher. We therefore performed flying pollinator and ant exclosure experiments in both a high-shade farm and a low-shade farm. Previous studies in our study sites confirm that the diversity of ants and some flying pollinators, such as bees, are higher in the high-shade farm compared to the low-shade farm (Ibarra-Núñez et al. 1995; Perfecto and Vandermeer 2002; Armbrecht and Perfecto 2003; Philpott et al. in press).

\section{Methods}

\section{Site description and flowering phenology}

We conducted our study in two coffee farms in the Soconusco region of SW Chiapas, Mexico: (1) Finca Irlanda $\left(15^{\circ} 11^{\prime} \mathrm{N}, 92^{\circ} 20^{\prime} \mathrm{W}\right)$ and (2) Finca Hamburgo $\left(15^{\circ} 10^{\prime} \mathrm{N}, 92^{\circ} 19^{\prime} \mathrm{W}\right)$ located $40 \mathrm{~km}$ NE of Tapachula. Both farms are located from 1000 to $1100 \mathrm{~m}$ a.s.l. To investigate differences with respect to pollination between two coffee management systems, we chose two farms differing in shade cover. Finca Irlanda, the high-shade site, has higher tree richness, abundance, percent shade cover, and structural depth than Finca Hamburgo, the low-shade site (Mas and Dietsch 2003; Philpott 2004). Although both farms cultivate multiple varieties of $C$. arabica, all study areas are dominated by var. Typica. According to Moguel and Toledo (1999), Irlanda corresponds to a "commercial polyculture" whereas Hamburgo is a "shaded monoculture". Finca Irlanda is a certified organic farm, and no fungicides or pesticides have been used in Finca Hamburgo for at least 4 years (Perfecto and Vandermeer 2002). Although the two farms do not differ in terms of soil classification or texture, Finca Hamburgo has higher concentrations of some nutrients (Potassium, Phosphorous, and Nitrate) due to chemical fertilizer use and soil acidity is higher in Finca Irlanda (K. Avilés-Vázquez, unpublished data).

In the study region, coffee flowers synchronously between February and April and fruits are harvested from September to December of the same year (personal observation). The main flowering event occurs in the dry season immediately following a rain event, with sporadic flowering $(\sim 5-10 \%$ of flowers) throughout the year. We conducted our study during the coffee growing season of 2002. During this year, flowering occurred in the study sites from 10 March to 25 April. In general, coffee flowers remain open for approximately 2 days (Free 1993), however, if flowers are not pollinated, they may remain open for at least 5 days (Jiménez-Castano and Castillo-Zapata 1976; Free 1993). Normally, coffee fruits contain two seeds, but occasionally only one ovary develops, a condition known as peaberry (Free 1993). 


\section{Pollinator exclosures and observations}

To test for effects of flying pollinators and/or ants compared to the ability of coffee to self pollinate, we established exclosure experiments in both farms. In each farm, we established 15 replicate blocks, consisting of three coffee plants. Plants were randomly assigned to one of three treatments: (1) open to flying pollinators and ants (open), (2) open to flying pollinators without ants (noant), or (3) without flying pollinators or ants (bagged). One branch per plant approximately $1 \mathrm{~m}$ above ground was treated. In the no-ant and bagged treatments, we eliminated ants by putting Tanglefoot ${ }^{\circledR}$ around the base of branches and by removing other vegetation making a bridge for ants. Additionally, on bagged branches, we placed bags $(0.5 \times 0.5 \mathrm{~mm}$ mesh) around entire coffee branches when flower buds were small $(\sim 1$ month before flowering), and removed bags only after all flowers had fallen. Mesh bags were removed immediately after coffee flowering; however, Tanglefoot ${ }^{\circledR}$ was not completely cleaned off branches until after the coffee harvest. Thus, bagged and no-ant branches contained Tanglefoot ${ }^{\circledR}$, but mesh bags were placed only on the bagged treatment.

For each experimental branch, we recorded number of flower buds, number of harvestable coffee fruits, weight per coffee fruit, and calculated the final fruit set (\# coffee fruits/\# flower buds) per branch. We counted flower buds in January 2002 in the high-shade farm and in February 2002 in the low-shade farm, due to slightly later development in the low-shade site. We harvested coffee fruits when the actual harvest began in the high-shade farm (October 2002). We tested for significant differences in numbers of coffee buds, fruits, fruit set, and fruit weight using two-way ANOVA using treatment and site as main factors, and block as a random factor. We used Tukey's post-hoc tests to determine significant differences between treatments in each site. We used raw data for numbers of flower buds and natural logarithm transformed data for number of fruits, fruit set, and fruit weight in all analyses to meet conditions of normality.

We made preliminary studies of flying pollinator and ant communities in study areas. Between 8:00 am and 1:00 pm, we observed coffee plants for 10 min each, recording order or morphospecies of all flying insects visiting coffee flowers during the observation period. We observed flying pollinators in 2002 only in the high-shade site (10 plants) during the height of the flowering event (26 and 27 March) and observed pollinators in both high- (10 plants) and low-shade sites (10 plants) during flowering events the following year (21 and 22 March 2003). Protocol for both years was the same. We conducted ant surveys during July 2002. We placed small $(2 \mathrm{~g})$ tuna baits on each coffee plant included in the experiment, and recorded both identity and activity level of ants. We checked tuna baits 30-45 min after they were placed and recorded ant activity per species at each bait with the following index: (1) 1-2 ants, (2) $3-10$ ants, (3) > 10 ants. To compare richness of flying pollinators and ants in the two sites, we generated sample-based rarefaction curves (MaoTao estimates) using EstimateS Version 7.5 (Colwell and Coddington 1994; 
http://www/viceroy/eeb/uconn/.edu/estimates). It is recommended to use sample-based rarefaction curves rescaled as the number of individuals to best compare richness between two sites (Gotelli and Colwell 2001). Yet, because of the social nature of ants, it is advised to use presence/absence (or incidence) data rather than abundance and correspondingly the number of species occurrences rather than number of individuals should be used when graphing species accumulation (Longino et al. 2002). Statistical comparisons of richness are made possible using MaoTao estimates as the corresponding $95 \%$ confidence intervals both produced using analytical formulas rather than re-sampling techniques. Voucher specimens of all ants and flying pollinators were collected and are stored at the University of Michigan.

\section{Results}

\section{Pollination}

There were no significant differences between treatments (open, no-ant, or bagged) in terms of numbers of flower buds, total fruits per branch, or in final fruit set (Table 1). In contrast, fruit weights were significantly higher on open branches than on no-ant or bagged branches, but only in the high-shade site (Table 1). In the high-shade site, fruits on open branches were significantly heavier than fruits on bagged $(p<0.001)$ and no-ant branches $(p<0.001)$ whereas, in the low-shade site, fruit weights on open branches did not differ from bagged ( $p=0.228$ ) or no-ant ( $p=0.107$ ) branches. Furthermore, coffee fruits were heavier in the high-shade site than in the low-shade site $(p<0.001$, $F=48.6, \mathrm{df}=1)$.

\section{Pollinator diversity and activity}

Ant surveys revealed a total of 13 ant morphospecies (Table 2). We encountered 10 morphospecies in the high-shade site, and 8 in the low-shade site. Observed sample-based rarefaction curves generated with EstimateS show that we did not sample the majority of the ant community in either site (i.e. our curves did not reach asymptotes) (Figure 1a). Comparing curves and 95\% confidence intervals for the high- and low-shade sites showed that although richness is higher in high-shade sites, this is likely not a significant difference. Ant activity did not significantly differ between the two sites ( $t$-test, $p=0.660$, $\mathrm{df}=86$ ), although mean activity was somewhat higher in the high-shade site $(2.11 \pm 0.23(\mathrm{SE}))$ than in the low-shade site $(1.97 \pm 0.19)$. Additionally, although we did not formally collect data on ants visiting coffee flowers, we saw several ant species (including Crematogaster spp., Myrmelachista spp., Pseudomyrmex spp., and Brachymyrmex spp.) on and around coffee flowers (S. Philpott, personal observation). 
Table 1. Mean $( \pm \mathrm{SE})$ for numbers of flower buds and fruits, fruit set, and fruit weights in high(Irlanda) and low-shade (Hamburgo) sites. Statistics are for two-way ANOVA using treatment (open, no-ant, or bagged) and site (high and low-shade) as main factors and block a random factor. Sample sizes were: high-shade open $(N=15)$, no-ants $(N=15)$, bagged $(N=15)$; low-shade open $(N=14)$, no-ants $(N=13)$, and bagged $(N=13)$. Superscripts indicate significant differences between treatments within a site and bold print shows significant differences.

\begin{tabular}{|c|c|c|c|c|c|}
\hline & & \# Flower buds & \# Fruits & Fruit set & Fruit weight (g) \\
\hline \multirow[t]{3}{*}{ High-shade } & Bagged & $91.38 \pm 13.25$ & $40.92 \pm 3.12$ & $0.57 \pm 0.096$ & $1.05 \pm 0.049^{\mathrm{b}}$ \\
\hline & No-ants & $86.15 \pm 13.14$ & $46.38 \pm 8.22$ & $0.54 \pm 0.069$ & $1.03 \pm 0.029^{\mathrm{b}}$ \\
\hline & Open & $97.35 \pm 11.41$ & $45.07 \pm 6.70$ & $0.51 \pm 0.078$ & $1.78 \pm 0.312^{\mathrm{a}}$ \\
\hline \multirow[t]{3}{*}{ Low-shade } & Bagged & $90.60 \pm 7.66$ & $48.46 \pm 6.61$ & $0.54 \pm 0.064$ & $0.81 \pm 0.031$ \\
\hline & No-ants & $131.86 \pm 17.65$ & $61.87 \pm 7.05$ & $0.53 \pm 0.058$ & $0.80 \pm 0.038$ \\
\hline & Open & $83.87 \pm 12.01$ & $39.80 \pm 4.81$ & $0.50 \pm 0.045$ & $0.90 \pm 0.024$ \\
\hline \multirow[t]{3}{*}{ Treatment } & $p$ & 0.3 & 0.204 & 0.686 & $<0.001$ \\
\hline & $F$ & 1.255 & 1.683 & 0.382 & 13.543 \\
\hline & $\mathrm{df}$ & 2 & 2 & 2 & 2 \\
\hline \multirow[t]{3}{*}{ Site } & $p$ & 0.289 & 0.144 & 0.613 & $<0.001$ \\
\hline & $F$ & 1.222 & 2.416 & 0.269 & 48.6 \\
\hline & $\mathrm{df}$ & 1 & 1 & 1 & 1 \\
\hline \multirow[t]{3}{*}{ Block } & $p$ & 0.738 & 0.428 & 0.762 & 0.942 \\
\hline & $F$ & 0.693 & 1.142 & 0.661 & 0.397 \\
\hline & $\mathrm{df}$ & 14 & 14 & 14 & 14 \\
\hline \multirow[t]{3}{*}{ Treatment $\times$ site } & $p$ & 0.054 & 0.313 & 0.742 & 0.035 \\
\hline & $F$ & 3.294 & 1.218 & 0.302 & 3.866 \\
\hline & $\mathrm{df}$ & 2 & 24 & 2 & 1 \\
\hline \multirow[t]{3}{*}{ Treatment $\times$ block } & $p$ & 0.652 & 0.489 & 0.574 & 0.321 \\
\hline & $F$ & 0.86 & 1.015 & 0.933 & 1.208 \\
\hline & $\mathrm{df}$ & 28 & 28 & 28 & 28 \\
\hline \multirow[t]{3}{*}{ Site $\times$ block } & $p$ & 0.138 & 0.121 & 0.215 & 0.329 \\
\hline & $F$ & 1.654 & 1.72 & 1.433 & 1.212 \\
\hline & $\mathrm{df}$ & 13 & 13 & 13 & 13 \\
\hline
\end{tabular}

We observed a total of 14 flying pollinator species visiting coffee flowers in surveys; 14 species occurred in the high-shade site and 5 were seen in the lowshade site (Table 3). Hymenoptera were the most frequent visitors accounting for $76 \%$ of total visits, with Trigona spp. and Apis mellifera making up 43.7\% and $12.7 \%$ of visits, respectively. Dipterans accounted for $18.3 \%$ of visits. As for ant surveys, sample-based rarefaction curves generated with EstimateS did not reach asymptotes and also demonstrate that flying pollinator richness in the high- and low-shade sites does not differ (Figure 1b). The number of visits per plant in the high-shade site $(3.39 \pm 0.61)$ was more than double that for the low-shade site $(1.25 \pm 0.25)(t=-2.272, \mathrm{df}=24, p=0.032)$.

\section{Discussion}

Surprisingly, fruit set was not higher on open or no-ant branches (both with flying pollinators) than on bagged branches. Nor were coffee fruit weights 
Table 2. Species list and activity levels for ants on tuna baits in the high-shade (Finca Irlanda) and low-shade (Finca Hamburgo) sites. Activity levels were calculated using an index where $1=1$ to 2 ants, $2=3$ to 10 ants, and $3=$ more than 10 ants. Total average activity levels were not significantly different between farms.

\begin{tabular}{lcc}
\hline Species & High-shade & Low-shade \\
\hline Azteca instabilis & 0 & 1 \\
Azteca sp. 1 & 1 & 0 \\
Brachymyrmex sp. 1 & 7 & 4 \\
Brachymyrmex sp. 2 & 6 & 3 \\
Camponotus senex textor & 1 & 1 \\
Crematogaster sp. & 0 & 7 \\
Dolichoderinae sp. 1 & 0 & 1 \\
Pheidole sp. 1 & 4 & 0 \\
Pheidole sp. 2 & 4 & 0 \\
Pheidole sp. 3 & 1 & 0 \\
Solenopsis geminata & 2 & 2 \\
Solenopsis sp. 1 & 2 & 0 \\
Wasmannia auropunctata & 1 & 8 \\
Total species richness & 10 & 1.9 \\
Average activity level & 2.17 & 60 \\
Number of plants sampled & 28 & \\
\hline
\end{tabular}
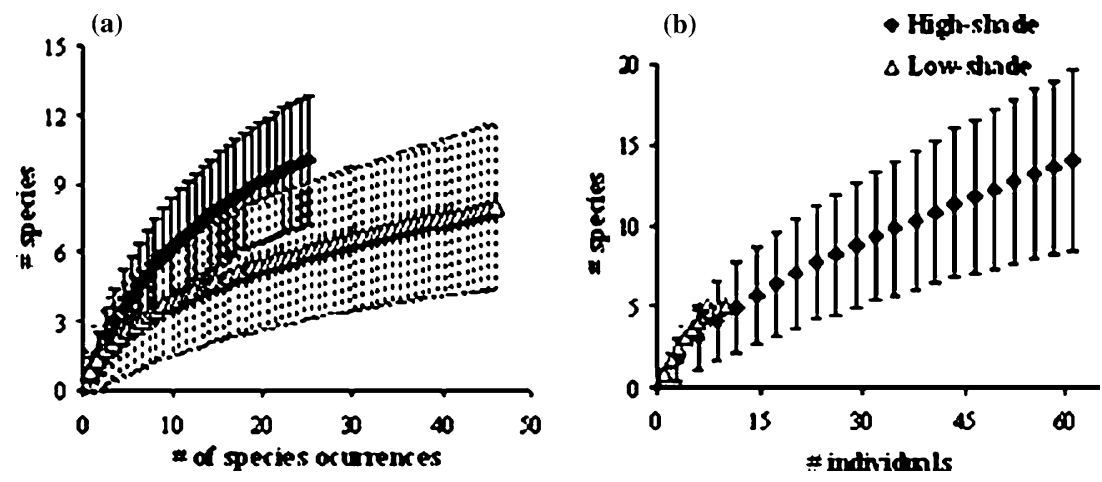

Figure 1. Sample-based rarefaction curves for ants (a) and flying pollinators (b) in the high- and low-shade sites. Curves were created using Mao-Tao estimates in EstimateS Version 7.5 using incidence data for ants and abundance data for flying pollinators. Ants are plotted by \# of individual occurrences and bees against number of individuals to best compare richness between the two management types (see text for full explanation). Error bars are analytically derived $95 \%$ confidence intervals. Black diamonds represent the high-shade site and open triangles represent the low-shade site.

higher on branches only with flying pollinators (no-ant) compared to bagged branches in either site. We thus reject our first hypothesis that flying pollinators alone positively influence coffee fruit set or weight, and do not further examine the implications of flying pollinator diversity for coffee pollination thoroughly addressed in other studies (Klein et al. 2003b). 
Table 3. Species list and activity levels for flying pollinators in the high-shade (Finca Irlanda) and low-shade (Finca Hamburgo) sites. Pollinator observations were based on 10 min observations for each of 20 and 10 coffee plants in the high- and low-shade sites, respectively.

\begin{tabular}{llcc}
\hline Order & Species & High-shade & Low-shade \\
\hline Coleoptera & Coleoptera sp. 1 & 1 & \\
Diptera & Coleoptera sp. 2 & 1 & \\
& Bombyliidae sp. 1 & 1 & 1 \\
Hymenoptera & Diptera sp. 1 & 10 & 2 \\
& Dolichopodidae sp. 1 & 1 & \\
& Apis mellifera & 7 & 3 \\
& Ceratina sp. 1 & 4 & 2 \\
& Ceratina sp. 2 & 3 & \\
& Trigona sp. 1 & 28 & 2 \\
Lepidoptera & Trigona sp. 2 & 1 & \\
Odonata & Vespidae sp. 1 & 1 & \\
Total species richness & Lepidoptera sp. 1 & 1 & 5 \\
Total number of visits & Odonata sp. 1 & 1 & 10 \\
Number of plants observed & & 14 & 10 \\
\hline
\end{tabular}

Coffee fruits on open branches (with flying pollinators and ants), however, were significantly heavier than fruits on no-ant and bagged branches in only the high-shade site. These results could stem from positive influences of ants on coffee fruit weights or from an interaction between flying pollinators and ants. Because fruit weights were higher on open branches only in the high-shade site implies that some change in ants (diversity, activity, and/or species composition) may explain differences between high and low-shade sites. Especially because we did not include a treatment with ants, but without flying pollinators, we cannot rule out the likely possibility that some interaction between ants and flying pollinators may have resulted in increased coffee fruit weights especially given that the number of flying pollinator visits was significantly higher in the high-shade site. Using our current data, we cannot determine which mechanisms are responsible for increased fruit weight, but suggest several potentially testable mechanisms either resulting from (1) indirect effects of ants via their interactions with flying pollinators and/or (2) direct effects of ants on pollination or fruit maturation.

\section{Indirect effects of ants}

Given that ants are not often direct pollinators, it is more likely that coffee fruit weights increased as a result of an interaction between ants and flying pollinators. Most perplexing, perhaps, is determining how ants or ant-flying pollinator interactions may result in increased fruit weight without influencing fruit 
set. In a self-compatible plant such as arabica coffee, fruit set is often not reduced without pollinators (Free 1993). Pollen load, however, may affect size and numbers of seeds or fruits (Winsor et al. 1987; Quesada et al. 1993) or probability of seed and fruit abortion (Bawa and Webb 1984; Stephenson and Winsor 1986; Casper 1988; Lee 1988; Nakamura 1988; Niesenbaum and Casper 1994; Niesenbaum 1999) even in self-fertile species (Morandin et al. 2001). High pollen loads can also lead to faster pollen tube growth, earlier fertilization, and thus a longer maturation period (Niesenbaum 1999). Pollen deposition on coffee flowers is enhanced by pollinators (Ricketts 2004) and such increased pollen loads may influence fruit weights. Given the short time coffee flowers are open (up to 5 days) and relatively long maturation time of coffee fruits (up to 7 months), this explanation seems unlikely. Larger pollen loads may also provide plants with higher donor diversity and thus genetic diversity of pollen. Thus, one possibility in coffee, as in other plants, is that increased pollen diversity leads to more pollen competition, increased pollen vigor and subsequent increases in fruit weight and overall quality (Bjorkman 1995; Paschke et al. 2002). Ants may be aggressive towards flying pollinators (A. Klein, personal communication), and may increase relocation frequency of pollinators thereby increasing pollen transfer, pollen load, and number of pollen donors (Altshuler 1999). Thus, ant aggression may increase movement of flying pollinators increasing pollen diversity, and perhaps increasing fruit weights.

\section{Direct effects of ants}

Ants may also increase coffee fruit weights either by directly depositing pollen on coffee stigmas or by influencing some aspect of fruit maturation. The coffee berry borer (Hypothenemus hampei Ferrari) attacks coffee fruits significantly reducing the weight of coffee beans (Damon 2000). We did not examine harvested fruits for berry borer attack, but ants prey on the berry borer (Velez et al. 2000, 2001). Thus, higher rates of berry borer attack on no-ant branches could account for lower fruit weights. Also, fruits on no-ant and bagged branches were nearly two times lighter than fruits on open branches in the high-shade site hinting to the pea-berry condition whereby only one of two coffee ovaries mature to a seed. Raw and Free (1977) and Klein et al. (2003b) reported pea-berry incidences of near $20 \%$ and $0.92 \%$, respectively. We did not count number of seeds per fruit to verify the number of pea-berries, but based on previous numbers, this mechanism is an unlikely explanation for our results of lighter fruits in approximately $5 / 6$ of fruits weighed.

\section{Differences between management systems}

Average fruit weights were higher in the high-shade farm potentially resulting from many factors. Muschler (2001) found that under high-shade conditions, 
coffee fruits (and beans) were significantly heavier (and thus of better quality) than when grown in full sun. It is possible that smaller differences in shade, like those between our high-shade and low-shade sites, may influence fruit weight as well. Fruit weight effects may be due to pollination, but there are potentially many differences between high-shade and low-shade sites, including edaphic factors or nutrient availability, that may influence fruit weights. In fact, availability of some nutrients is higher in our high-shade site (K. AvilésVázquez, unpublished data). Fruit weights were significantly higher overall in the high-shade site, potentially pointing to limitation in nutrients necessary for fruit maturation in the low-shade site. These site differences may account for higher fruit weights in the high-shade farm, and may potentially have also affected increases in fruit weight specifically on the open branches compared with bagged or no-ant branches.

Biological differences in the pollinator community between sites, however, may also have played a role in increasing fruit weights. Ant species richness was slightly higher the high-shade site, but for data presented here was not significantly higher. Previous and more extensive ant sampling in the same sites, however, has revealed significantly higher ant richness in the high-shade site (Ibarra-Núñez et al. 1995; Perfecto and Vandermeer 2002; Armbrecht and Perfecto 2003). Ant activity was not significantly different between the two sites. Here, we observed nearly three times as many species in the high-shade site, and numbers of flying pollinator visits were twice as high in the high-shade site. Additionally, Ibarra-Núñez et al. (1995), working in the same sites, sampled coffee plants on a monthly basis for a 3 year period and collected twice as many ant individuals in the high-shade site $(12,843)$ than in the lowshade site (6097). Furthermore, they collected 19 bee species in the high-shade site and 7 bee species in the low-shade site. Thus, there are potentially many differences in the pollinator communities (i.e. higher ant richness, presence of a particular ant species, increased visitation rates by flying pollinators) or particular interaction between ants and bees only in the high-shade site may account for fruit weight differences between the two sites. Changes in ant species composition may be especially important if ants function to directly increase pollen loads or cause flying pollinators to relocate more frequently, or prey on coffee berry borers.

\section{Suggestions for future work}

Several tests could be carried out to begin to determine if ant-pollinator interactions or ants are responsible for increasing fruit weights via pollination or influencing aspects of maturation. To study if site differences (i.e. nutrient limitation or edaphic factors) or differences caused by pollination (i.e. pollen load, pollen diversity) are responsible for differences in fruit weights, hand pollination experiments could be conducted. If, for example, a lack of nutrients or water in low-shade sites is limiting fruit weights, pollen addition to flowers 
would not be expected to influence fruit weights in these sights, but would in high-shade sites where nutrients and water are not limiting. Furthermore, by using multiple pollen addition treatments (increase in self pollen, increase in outcross from only one plant, increase in outcross pollen from several plants), factors relating to pollen load and pollen diversity and their respective influences on fruit set and/or fruit weights could be elucidated. To determine if, ants may be responsible for increasing activity of flying pollinators, observations of visitation rates (in terms of both number and length of visits) could be compared for branches, or farm areas, with and without high ant activity. To distinguish if ants affect pollination or aspects of fruit maturation Tanglefoot ${ }^{\circledR}$ application could be applied only during flowering (pollination effect) and only after flowering until the harvest (maturation effect). In order to determine if ants affect fruit weights limiting berry borers, the number of attacked fruits, and individual weights of attacked berries could be quantified for branches with and without ants. Furthermore, to ensure that pea-berries do not account for differences, berries could either be checked for deformities or opened to check for presence of two seeds. Those differences potentially caused by differences in the pollinator community between the two sites are clearly more difficult to test. Nonetheless, by first clarifying some of the other potential mechanisms would likely shed light on the role of ants and flying pollinators under the two types of shade management system.

\section{Conclusion}

In conclusion, we observed increased fruit weights in the high-shade site likely resulting from differences associated with management, including differences in the pollinator community. Higher fruit weights provide advantages to plants in terms of germination or seedling growth (Ngulube et al. 1997; Eriksson 1999) or in other aspects of plant reproductive biology (Tremayne and Richards 2000; Mukasa and Ogata 2001; Schippers et al. 2001). Furthermore, increased fruit weights confer obvious economic advantages to coffee farmers. Regardless of which mechanisms influence fruit weight on branches only with flying pollinators and ants in high-shade farms, this finding will have important implications for the maintenance of shaded coffee farms and biodiversity in general (Moguel and Toledo 1999).

\section{Acknowledgements}

F. Hernández Gómez, L.A. Maldonado Alvarado, B.E. Chilel, F. Camposeco Silvestre, J. Cabrera Santos, G. López Bautista, J.A. García Ballinas, and A. González González provided field assistance. P. Bichier, A. Klein, C. Landry, I. Perfecto, B. Rathcke, M. Reiskind, S. Schueller, and J. Vandermeer provided thoughtful discussions and comments on the manuscript. G. Ibarra-Núñez and 
El Colegio de la Frontera Sur in Tapachula provided logistical support. We thank the Peters and Edelmann families for permission to work on their farms. This study was partially funded by NSF grant \#DEB-9981526, the Helen Olsen Brower Fellowship in Environmental Science of the University of Michigan, and an NSF Graduate Research Fellowship.

\section{References}

Aizen M. and Feinsinger P. 1994. Forest fragmentation, pollination, and plant reproduction in a Chaco dry forest, Argentina. Ecology 75: 330-351.

Allen-Wardell G., Bernhardt P., Bitner R., Burquez A., Buchmann S., Cane J., Cox P.A., Dalton V., Feinsinger P., Ingram M., Inouye D., Jones C.E., Kennedy K., Kevan P., Koopowitz H., Medellin R., Medellin-Morales S., Nabhan G.P., Pavlik B., Tepedino V., Torchio P. and Walker S. 1998. The potential consequences of pollinator declines on the conservation of biodiversity and stability of food crop yields. Conserv. Biol. 12: 8-17.

Altshuler D.L. 1999. Novel interactions of non-pollinating ants with pollinators and fruit consumers in a tropical forest. Oecologia 119: 600-606.

Armbrecht I. and Perfecto I. 2003. Litter-dwelling ant species richness and predation potential within a forest fragment and neighboring coffee plantations of contrasting habitat quality in Mexico. Agric., Ecosyst. Environ. 97: 107-115.

Balvanera P., Daily G.C., Ehrlich P.R., Ricketts T.H., Bailey S.A., Kark S., Kremen C. and Pereira H. 2001. Conserving biodiversity and ecosystem services. Science 291: 2047-2047.

Bawa K. and Webb C. 1984. Flower, fruit and seed abortion in tropical trees: implications for the evolution of paternal and maternal reproductive patterns. Am. J. Bot. 71: 736-751.

Beattie A.J., Turnbull C., Knox R.B. and Williams E.G. 1984. Ant inhibition of pollen function - a possible reason why ant pollination is rare. Am. J. Bot. 71: 421-426.

Bjorkman T. 1995. The effect of pollen load and pollen grain competition on fertilization success and progeny performance in Fagopyrum esculentum. Euphytica 83: 47-52.

Calvo L. and Blake J. 1998. Bird diversity and abundance on two different shade coffee plantations in Guatemala. Bird Conserv. Int. 8: 297-308.

Casper B. 1988. Evidence for selective embryo abortion in Crypantha flava. Am. Nat. 132: 318-326.

Colwell R.K. and Coddington J. 1994. Estimating terrestrial biodiversity through extrapolation. In: Hawksworth D. (ed.), Bio-diversity: Measurement and Estimation. London.

Colwell R.K., Mao C.X. and Chang J. 2004. Interpolating, extrapolating, and comparing incidence-based species accumulation curves. Ecology 85: 2717-2727.

Cunningham S.A., FitzGibbon F. and Heard T.A. 2002. The future of pollinators for Australian agriculture. Aust. J. Agric. Res. 53: 893-900.

Damon A. 2000. A review of the biology and control of the coffee berry borer, Hypothenemus hampei (Coleoptera: Scolytidae). Bull. Entomol. Res. 90: 453-465.

Eriksson O. 1999. Seed size variation and its effect on germination and seedling performance in the clonal herb Convallaria majalis. Acta Oecol. Int. J. Ecol. 20: 61-66.

Free J.B. 1993. Insect Pollination of Crops. Academic Press, London.

Galen C. 1999. Flowers and enemies: predation by nectar-thieving ants in relation to variation in floral form of an alpine wildflower, Polemonium viscosum. Oikos 85: 426-434.

Galen C. and Cuba J. 2001. Down the tube: Pollinators, predators, and the evolution of flower shape in the alpine skypilot, Polemonium viscosum. Evolution 55: 1963-1971.

Garcia M.B., Antor R.J. and Espadaler X. 1995. Ant pollination of the palaeoendemic dioecious Borderea pyrenaica (Dioscoreaceae). Plant Systematics and Evolution 198: 17-27.

Ghazoul J. 2001. Can floral repellents pre-empt potential ant-plant conflicts? Ecol. Lett. 4: 295-299. 
Gomez J.M. 2000. Effectiveness of ants as pollinators of Lobularia maritima: effects on main sequential fitness components of the host plant. Oecologia 122: 90-97.

Gomez J.M. and Zamora R. 1992. Pollination by ants - consequences of the quantitative effects on a mutualistic system. Oecologia 91: 410-418.

Gomez J.M., Zamora R., Hodar J.A. and García D. 1996. Experimental study of pollination by ants in Mediterranean high mountain and arid habitats. Oecologia 105: 236-242.

Gotelli N. and Colwell R.K. 2001. Quantifying biodiversity: procedures and pitfalls in the measurement and comparison of species richness. Ecol. Lett. 4: 379-391.

Guerrant E.O. and Fiedler P.L. 1981. Flower defenses against nectar-pilferage by ants. Biotropica 13: $25-33$.

Ibarra-Núñez G., García J. and Moreno M. 1995. Diferencias entre un cafetal orgánico y uno convencional en cuanto a diversidad y abundancia de dos grupos de insectos. In: Ibarra-Núñez G., García J. and Moreno M. (eds), Primera conferencia internacional IFOAM sobre café orgánico. México, pp. 115-129.

Jiménez-Castano W. and Castillo-Zapata J. 1976. Observaciones sobre la polinización de Coffea arabica L. en la zona cafetera central de Colombia. Cenicafe 27: 51-66.

Kearns C.A., Inouye D.W. and Waser N.M. 1998. Endangered mutualisms: The conservation of plant-pollinator interactions. Ann. Rev. Ecol. Syst. 29: 83-112.

Klein A.M., Steffan-Dewenter I., Buchori D. and Tscharntke T. 2002. Effects of land-use intensity in tropical agroforestry systems on coffee flower-visiting and trap-nesting bees and wasps. Conserv. Biol. 16: 1003-1014.

Klein A.M., Steffan-Dewenter I. and Tscharntke T. 2003a. Bee pollination and fruit set of Coffea arabica and C. canephora (Rubiaceae). Am. J. Bot. 90: 153-157.

Klein A.M., Steffan-Dewenter I. and Tscharntke T. 2003b. Fruit set of highland coffee increases with the diversity of pollinating bees. Proc. Roy. Soc. Lond., B 270: 955-961.

Kremen C., Williams N.M. and Thorp R.W. 2002. Crop pollination from native bees at risk from agricultural intensification. Proc. Natl. Acad. Sci. USA 99: 16812-16816.

Lee T. 1988. Patterns of fruit and seed production. In: Doust J. and Doust L. (eds), Plant Reproductive Ecology: Patterns and Strategies. New York, New York, pp. 79-202.

Longino J.T., Coddington J. and Colwell R.K. 2002. The ant fauna of a tropical rain forest: estimating species richness three different ways. Ecology 83: 689-702.

Manrique A.J. and Thimann R.E. 2002. Coffee (Coffea arabica) pollination with Africanized honeybees in Venezuela. Interciencia 27: 414-416.

Mas A.H. and Dietsch T.V. 2003. An index of management4 intensity for coffee agroecosystems to evaluate butterfly species richness. Ecol. Appl. 13: 1491-1501.

Moguel P. and Toledo V.M. 1999. Biodiversity conservation in traditional coffee systems of Mexico. Conserv. Biol. 13: 11-21.

Morandin L.A., Laverty T.M. and Kevan P.G. 2001. Effect of bumble bee (Hymenoptera: Apidae) pollination intensity on the quality of greenhouse tomatoes. J. Econ. Entomol. 94: 172-179.

Mukasa Y. and Ogata N. 2001. Correlation of early growth with average germination period and true seed weight in sugar beet under direct sowing cultivation. Jpn. J. Crop Sci. 70: 510-514.

Muschler R.G. 2001. Shade improves coffee quality in a sub-optimal coffee-zone of Costa Rica. Agroforest. Syst. 51: 131-139.

Myers N. 1996. Environmental services of biodiversity. Proc. Natl. Acad. Sci. USA 93: 2764-2769.

Nakamura R. 1988. Seed abortion and seed size variation within fruits of Phaseolus vulgaris: pollen donor and resource variation effects. Am. J. Bot. 75: 1003-1010.

Ngulube M.R., Hall J.B. and Maghembe J.A. 1997. Fruit, seed and seedling variation in Uapaca kirkiana from natural populations in Malawi. For. Ecol. Manage. 98: 209-219.

Niesenbaum R. 1999. The effects of pollen load size and donor diversity on pollen performance, selective abortion, and progeny vigor in Mirablils jalapa. Am. J. Bot. 86: 261-268.

Niesenbaum R. and Casper B. 1994. Pollen tube numbers and selective fruit maturation in Lindera benzoin. Am. Nat. 144: 184-191.

Nogueira-Neto P., Carvalho A. and Antunes H. 1959. Efeito da exclusa o dos insetos polinizadores na produç a o do cafe' Bourbon. Bragantia 18: 441-468. 
Norberg J. 1999. Linking Nature's services to ecosystems: some general ecological concepts. Ecol. Econ. 29: 183-202.

Oliveira P.S. 1997. The ecological function of extrafloral nectaries: Herbivore deterrence by visiting ants and reproductive output in Caryocar brasiliense (Caryocaraceae). Funct. Ecol. 11: 323-330.

Oliveira P.S., Rico-Gray V., Díaz-Castelazo C. and Castillo-Guevara C. 1999. Interaction between ants, extrafloral nectaries and insect herbivores in Neotropical coastal sand dunes: herbivore deterrence by visiting ants increases fruit set in Opuntia stricta (Cactaceae). Funct. Ecol. 13: 623-631.

Paschke M., Abs C. and Schmid B. 2002. Effects of population size and pollen diversity on reproductive success and offspring size in the narrow endemic Cochlearia bavarica (Brassicaceae). Am. J. Bot. 89: 1250-1259.

Perfecto I. and Snelling R. 1995. Biodiversity and the transformation of a tropical agroecosystem ants in coffee plantations. Ecol. Appl. 5: 1084-1097.

Perfecto I. and Vandermeer J. 1996. Microclimatic changes and the indirect loss of ant diversity in a tropical agroecosystem. Oecologia 108: 577-582.

Perfecto I. and Vandermeer J. 2002. Quality of agroecological matrix in a tropical montane landscape: ants in coffee plantations in southern Mexico. Conserv. Biol. 16: 174-182.

Philpott S.M. 2004. The Diversity, Ecology, and Function of Arboreal Ants in Coffee Agroecosystems in Soconusco, Chiapas, Mexico. Department of Ecology and Evolutionary Biology, University of Michigan, Ann Arbor.

Philpott S.M., Perfecto I. and Vandermeer J. Effects of management intensity and season on arboreal ant diversity and abundance in coffee agroecosystems. Biodivers. Conserv.. In press.

Pimentel D., Wilson C., McCullum C., Huang R., Dwen P., Flack J., Tran Q., Saltman T. and Cliff B. 1997. Economic and environmental benefits of biodiversity. Bioscience 47: 747-757.

Quesada M., Winsor J.A. and Stephenson A.G. 1993. Effects of pollen competition on progeny performance in a heterozygous cucurbit. Am. Nat. 142: 694-706.

Ramsey M. 1995. Ant pollination of the perennial herb Blandfordia grandiflora (Liliaceae). Oikos 74: 265-272.

Rathcke B. and Jules E. 1993. Habitat fragmentation and plant-pollinator interactions. Curr. Sci. 65: 273-277.

Raw A. and Free J.B. 1977. Pollination of coffee (Coffea arabica) by honeybees. Trop. Agric. 54: 365-370.

Ricketts T.H. 2004. Tropical forest fragments enhance pollinator activity in nearby coffee crops. Conserv. Biol. 18: 1262-1271.

Ricketts T.H., Daily G.C., Ehrlich P.R. and Michener C.D. 2004. Economic value of tropical forest to coffee production. Proc. Natl. Acad. Sci. USA 101: 12579-12582.

Roubik D.W. 2002. Tropical agriculture - the value of bees to the coffee harvest. Nature 417: 708708 .

Schippers P., van Groenendael J.M., Vleeshouwers L.M. and Hunt R. 2001. Herbaceous plant strategies in disturbed habitats. Oikos 95: 198-210.

Sein F.Jr. 1959. [Do bees help coffee?] Hacienda 55: 36-50.

Sporleder M. and Rapp G. 1998. The effect of Oecophylla longinoda (Latr.) (Hym., Formicidae) on coconut palm productivity with respect to Pseudotheraptus wayi Brown (Hem., Coreidae) damage in Zanzibar. J. Appl. Entomol. - Zeitschrift Fur Angewandte Entomologie 122: $475-481$.

Steffan-Dewenter I. and Tscharntke T. 1999. Effects of habitat isolation on pollinator communities and seed set. Oecologia 121: 432-440.

Stephenson A.G. and Winsor J.A. 1986. Lotus corniculatus regulates offspring quality through selective fruit abortion. Evolution 40: 453-458.

Tremayne M.A. and Richards A.J. 2000. Seed weight and seed number affect subsequent fitness in outcrossing and selfing Primula species. New Phytol. 148: 127-142.

Velez M., Bustillo A.E. and Posada F.J. 2000. Predacion sobre Hypothenemus hampei, (Ferrari) de las hormigas Solenopsis spp., Pheidole spp., y Dorymyrmex spp. durante el secado del café. In: 
Vélez M., Bustillo A.E. and Posada F.J. (eds), Resúmenes XXVII Congreso. Sociedad Colombiana de Entomología, Medellín, Colombia, pp. 17.

Vélez M., Bustillo A.E. and Posada F.J. 2001. Hormigas de la zona central cafetera y perspectivas de su uso en el control de Hypothenemus hampei (Ferrari) (Coleoptera: Scolytidae). In: Vélez M., Bustillo A.E. and Posada F.J. (eds), Resúmenes XXVIII Congreso. Sociedad Colombiana de Entomología, Pereira, Colombia, pp. 51.

Wagner D. 2000. Pollen viability reduction as a potential cost of ant association for Acacia constricta (Fabaceae). Am. J. Bot. 87: 711-715.

Wagner D. and Kay A. 2002. Do extrafloral nectaries distract ants from visiting flowers? An experimental test of an overlooked hypothesis Evol. Ecol. Res. 4: 293-305.

Willmer P.G. and Stone G.N. 1997. How aggressive ant-guards assist seed-set in Acacia flowers. Nature 388: 165-167.

Winsor J.A., Davis L.E. and Stephenson A.G. 1987. The relationship between pollen load and fruit maturation and the effect of pollen load on offspring vigor in Cucurbita pepo. Am. Nat. 129: 643656.

Yano S. 1994. Flower nectar of an autogamous perennial Rorippa indica as an indirect defensemechanism against herbivorous insects. Res. Popul. Ecol. 36: 63-71. 